\title{
Length-Weight, Length-Length Relationships and Condition Factor of Grey Mullet Species From Köyceğiz Lagoon in Turkey
}

\author{
İsmail REİS $\mathbb{D}^{*}$, Celal ATEŞ®D
}

Muğla Sitkı Koçman University, Faculty of Fisheries, Department of Fishing Technology, Menteşe/Muğla, Turkey

*Corresponding Author: ismailreis@mu.edu.tr

Research Article

Received 16 March 2019; Accepted 09 April 2019; Release date 15 December 2019.

How to Cite: Reis, İ., \& Ateş, C. (2019). Length-weight, length-length relationships and condition factor of grey mullet species from Köyceğiz Lagoon in Turkey. Acta Aquatica Turcica, 15(4), 411-417. https://doi.org/10.22392/actaquatr.540983

\begin{abstract}
The relationships between length-weight, length-length parameters and condition factor were given for four grey mullet species that caught in Köyceğiz Lagoon area between January 2017 and December 2017. Total length and weight ranged from 6.2-39.3 cm and 2.34-508.38 $\mathrm{g}$ for Chelon auratus, 8.9-47.6 cm and 8.61-1006.5 $\mathrm{g}$ for Mugil cephalus, 5.0-37.7 cm and $1.62-478.90 \mathrm{~g}$ for Chelon labrosus and $3.8-35.2 \mathrm{~cm}$ and $0.52-462.88 \mathrm{~g}$ for Chelon saliens. The length-weight relationships were determined for $C$. auratus, $M$. cephalus, $C$. labrosus and $C$. saliens as $W=0.0087 \mathrm{~L}^{2.96}, W=0.0106 \mathrm{~L}^{2.95}, W=0.0073 \mathrm{~L}^{3.06}$ and $W=0.0067 \mathrm{~L}^{3.04}$ respectively. All the fish species showed isometric growth $(b=3)$. It was observed that there were strong correlations between total length, fork length and standard length of 4 fish species $(P<0.001)$. Also, the condition factor values range between 0.56-1.30 for C. auratus, 0.66-1.22 for M. cephalus, 0.64-1.30 for C. labrosus, 0.57-1.06 for C. saliens.
\end{abstract}

Keywords: Köyceğiz Lagoon, Fish barrier, grey mullet, growth

Köyceğiz Lagünü'nden (Türkiye) Avlanan Kefal Türlerinin Boy-Ağırlık, Boy-Boy Ilişkileri ve Kondüsyon Faktörü

Özet

Ocak 2017-Aralık 2017 tarihleri arasında Köyceğiz Lagününden avlanan dört farklı kefal türünün boy-ağırlık, boy-boy parametreleri ve kondüsyon faktörü değerleri verilmiştir. Total boy ve ağırlık değerleri Chelon auratus için 6,2-39,3 cm ve 2,34-508,38 g, Mugil cephalus için 8,9-47,6 cm ve 8,61-1006,5 g, Chelon labrosus için 5,0-37,7 cm ve 1,62-478,90 g, Chelon saliens için 3,8-35,2 cm ve 0.52-462,88 g olarak değişim göstermiştir. Boy-ağırlık ilişkisi denklemleri C. auratus, M. cephalus, $C$. labrosus ve $C$. saliens için sirasıly $W=0,0087 \mathrm{~L}^{2,96}, W=0,0106 \mathrm{~L}^{2,95}, W=0,0073 \mathrm{~L}^{3,06}$ ve $W=0,0067 \mathrm{~L}^{3,04}$ olarak tespit edilmiştir. Tüm balık türleri izometrik büyüme göstermiştir $(b=3)$. Total boy, çatal boy ve standart boy arasında bu dört balık türü için güçlü bir ilişki olduğu gözlemlenmiştir $(P<0,001)$. Ayrıca, kondüsyon faktörü değerleri $C$. auratus için $0,56-$ 1,30, M. cephalus için 0,66-1,22, C. labrosus için 0,64-1,30, C. saliens için 0,57-1,06 arasında değişim göstermiştir.

Anahtar Kelimeler: Köyceğiz Lagünü, dalyan, kefal, büyüme

\section{INTRODUCTION}

Köyceğiz Lagoon system covers 5400 hectares lake area and quagmire outlook 1150 hectares delta area and is connected to the sea via a $14 \mathrm{~km}$ long canal. The width of the canal varies between 5-70 meters and the depth between 1-6 meters (Buhan, 1998). Fishing activities are carried by DALKO (Dalyan Fisheries Cooperative) in the lagoon system. The lagoon area consists of four main sections; Lake Köyceğiz, lagoon canal, Lake Sülüngür and Lake İztuzu.

Köyceğiz Lagoon is one of the most important active lagoon fishery areas in Turkey (Sağlam et al., 2015). DALKO operates Turkish wooden dalyan which set up in this area. Besides being an active lagoon fisherycooperative, they also prepare and sell grey mullet caviar. 
Due to the high economic value of this product, it increases the significance of this area and grey mullet species. A great economic return comes out with both roe and fresh mullet flesh. These features are enough to think about the sustainability of lagoon fishery. As it is known by all fishery managers, fishery should be managed for food and economic sustainability.

The length-weight relationships (LWR) are one of the most useful parameters for fishery management and have importance in fisheries science. The LWR is used for prediction the weight corresponding to a given length and to allow for the comparison of fish growth in different regions or localities (Bagenal and Tesch, 1978; Moutopoulos and Stergiou, 2002; Tsoumani et al., 2006). LWR may also useful to determine whether somatic growth is isometric or allometric (Ricker, 1975).

Condition factor gives knowledge when comparing two populations in living different regions, climate and other conditions (Weatherly and Gills, 1987). Therefore, condition factor of fish species is important for understanding its life cycle.

This study aims to contribute to the knowledge of LWR, LLR and condition factor data for commercial grey mullet species, Chelon auratus (Risso, 1810), Mugil cephalus (Linnaeus, 1758), Chelon labrosus (Risso, 1827) and Chelon saliens (Risso, 1810), in Köyceğiz Lagoon.

\section{MATERIALS and METHODS}

Samples were collected monthly periods with Turkish wooden dalyan, trammel net, beach seine and cast-net between January 2017 and December 2017 in the Köyceğiz Lagoon, Turkey (Figure 1). The fish samples were brought to the laboratory and were taxonomically identified according to Thomson (1997); FAO (1999) and Geldiay and Balık (2009). Total length (TL), fork length (FL) and standard length (SL) were recorded to the nearest centimetre $(0.1 \mathrm{~cm})$, and bodyweight $(\mathrm{W})$ was measured with precision balance $(0.01 \mathrm{~g})$.

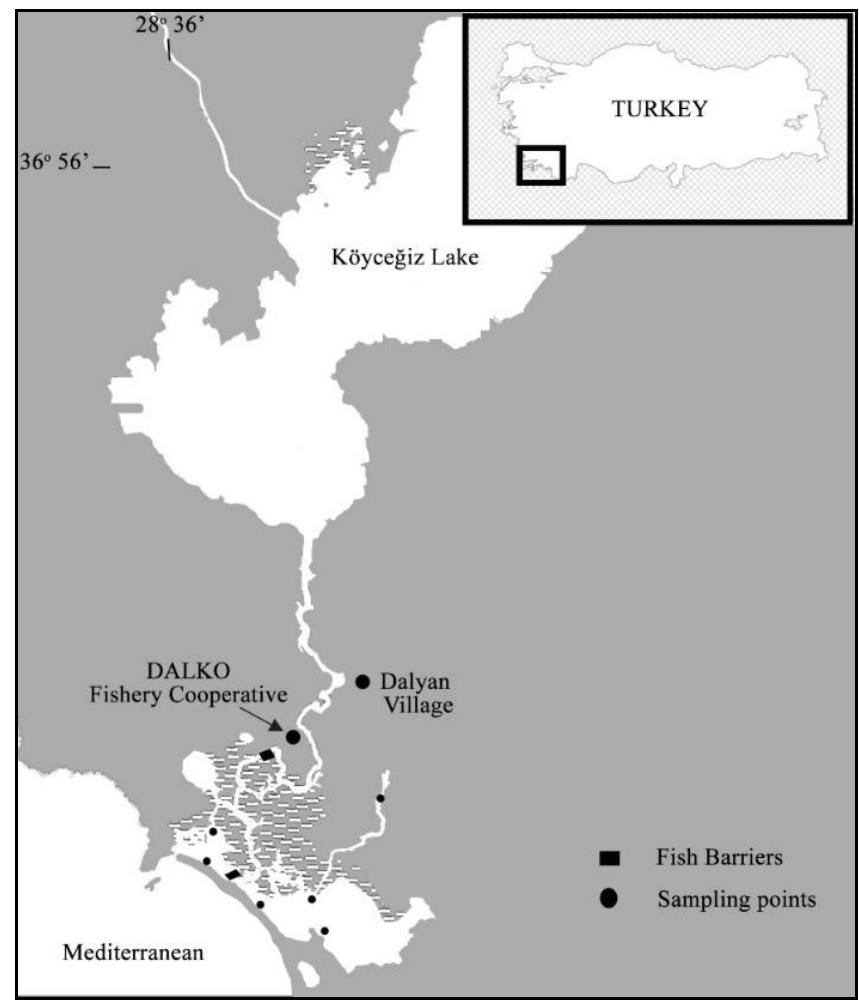

Figure 1. The study area

The length-weight relationships were established using the equation; $W=a L^{b}$, where $\mathrm{W}$ is weight $(\mathrm{g})$, $\mathrm{L}$ is length $(\mathrm{cm}), a$ is the intercept and $b$ is the slope of the linear regressions. The significance of the $b$-values for each species was tested by $t$-test to confirm that it was significantly different from the predictions for isometric growth $(b=3)$ (Pauly, 1993).

The length-length relationship was estimated by linear regression analysis: $\mathrm{TL}=a+b \mathrm{SL} ; \mathrm{FL}=a$ $+b \mathrm{SL}$ and $\mathrm{SL}=a+b \mathrm{FL}$, where $a$ is the intercept and $b$ is the slope of the linear regression. 
Fulton's condition factor $(\mathrm{K})$ was calculated using the equation; $\mathrm{K}=\left(\mathrm{W} / \mathrm{L}^{3}\right)^{*} 100$ where $\mathrm{W}$ is the total weight $(\mathrm{g}), \mathrm{L}$ is the total length $(\mathrm{cm})$.

The Microsoft Office Excel software (version 2016) was used for all calculations.

\section{RESULTS}

Overall, 1195 samples from 4 fish species C. auratus, M. cephalus, C. labrosus and C. saliens were examined in the Köyceğiz Lagoon in Turkey. C. auratus (476) was found the most abundant fish species.

Table 1. Parameters of the LWR and condition factor for four grey mullet species from the Köyceğiz Lagoon (Turkey)

\begin{tabular}{|c|c|c|c|c|c|c|c|c|c|c|}
\hline \multirow{2}{*}{ Species } & \multirow{2}{*}{$\mathrm{N}$} & \multirow{2}{*}{$\mathrm{K}_{\min }-\mathrm{K}_{\max }$} & \multirow{2}{*}{$\mathrm{L}_{\min }-\mathrm{L}_{\max }$} & \multirow{2}{*}{$\mathrm{W}_{\min }-\mathrm{W}_{\max }$} & \multicolumn{6}{|c|}{ Parameters of LWR } \\
\hline & & & & & $a$ & $b$ & $\mathrm{SE}(b)$ & $\mathbf{C I}(b)$ & $\mathbf{r}^{2}$ & GT \\
\hline C. auratus & 476 & $0.56-1.30$ & $6.2-39.3$ & $2.34-508.38$ & 0.0087 & 2.96 & 0.052 & $2.931-2.988$ & 0.989 & Isometric \\
\hline M. cephalus & 291 & $0.66-1.22$ & $8.9-47.6$ & $8.61-1006.5$ & 0.0106 & 2.95 & 0.042 & $2.914-2.983$ & 0.989 & Isometric \\
\hline C. labrosus & 279 & $0.64-1.30$ & $5.0-37.7$ & $1.62-478.9$ & 0.0073 & 3.065 & 0.058 & $3.027-3.103$ & 0.989 & Isometric \\
\hline C. saliens & 149 & $0.57-1.06$ & $3.8-35.2$ & $0.52-462.88$ & 0.0067 & 3.045 & 0.057 & 2.996-3.094 & 0.991 & Isometric \\
\hline
\end{tabular}

In this study, $b$ values were calculated between 2.95 (M. cephalus) and 3.065 (C. labrosus) (Table 1). In this experiment when the values of $b$ are examined, it was found that an isometric growth for all fish species. The $\mathrm{K}$ values significantly $(\mathrm{P}<0.001)$ range between $0.53-1.01$ for $C$. auratus, $0.70-$ 1.05 for M. cephalus, $0.73-1.13$ for $C$. labrosus and for $L$. saliens $0.57-1.06$. The condition factor and LWR parameters of the four grey mullet species are shown in Table 1.

Length - weight relationship of $C$. auratus, $M$. cephalus, C. labrosus and C. saliens are found $W=0.0087 \mathrm{~L}^{2.96}, W=0.0106 \mathrm{~L}^{2.95}, W=0.0073 \mathrm{~L}^{3.06}$ and $W=0.0067 \mathrm{~L}^{3.04}$ respectively (Figure 2 ).

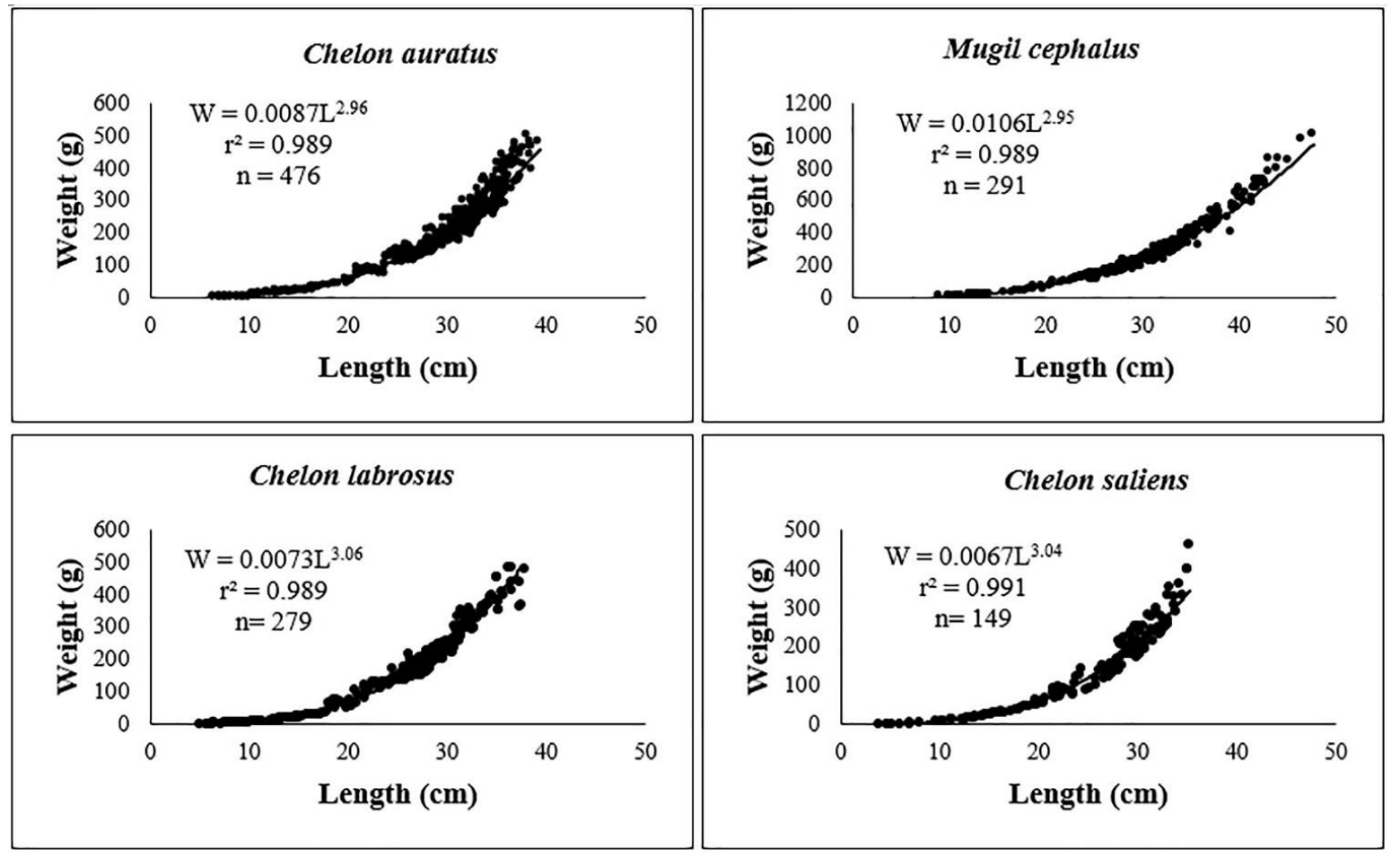

Figure 2. Length-weight relationships $\left(W=a \mathrm{~L}^{b}\right)$ for $C$. auratus, $M$. cephalus, C. labrosus and $C$. saliens from the Köyceğiz Lagoon in Turkey.

Relations between TL-FL, FL-SL and SL-TL of C. auratus, M. cephalus, C. labrosus and $C$. saliens living in Köyceğiz lagoon are given in Table 2. Significant relationships were found between different lenghts of each fish species $(\mathrm{P}<0.001)$. 
Table 2. Lenght-lenght relationships parameters of C. auratus, M. cephalus, C. labrosus and C. saliens from the Köyceğiz Lagoon in Turkey

\begin{tabular}{|c|c|c|c|c|c|c|c|}
\hline Species & $\mathrm{N}$ & Equation & $a$ & $b$ & $\operatorname{SE}(b)$ & $\mathrm{CI}(b)$ & $r^{2}$ \\
\hline \multirow{3}{*}{ C. auratus } & \multirow{3}{*}{476} & $\mathrm{TL}=a+b \mathrm{FL}$ & 0.149 & 0.897 & 0.292 & $0.895-0.900$ & 0.998 \\
\hline & & $\mathrm{FL}=a+b \mathrm{SL}$ & -0.490 & 0.870 & 0.361 & $0.866-0.874$ & 0.996 \\
\hline & & $\mathrm{SL}=a+b \mathrm{TL}$ & -0.349 & 0.780 & 0.485 & $0.776-0.785$ & 0.993 \\
\hline \multirow{3}{*}{ M. cephalus } & \multirow{3}{*}{291} & $\mathrm{TL}=a+b \mathrm{FL}$ & 0.115 & 0.899 & 0.314 & $0.896-0.903$ & 0.999 \\
\hline & & $\mathrm{FL}=a+b \mathrm{SL}$ & -0.283 & 0.864 & 0.243 & $0.861-0.867$ & 0.999 \\
\hline & & $\mathrm{SL}=a+b \mathrm{TL}$ & -0.182 & 0.778 & 0.378 & $0.773-0.782$ & 0.998 \\
\hline \multirow{3}{*}{ C. labrosus } & \multirow{3}{*}{279} & $\mathrm{TL}=a+b \mathrm{FL}$ & 0.226 & 0.888 & 0.271 & $0.884-0.892$ & 0.998 \\
\hline & & $\mathrm{FL}=a+b \mathrm{SL}$ & -0.127 & 0.861 & 0.307 & $0.855-0.866$ & 0.997 \\
\hline & & $\mathrm{SL}=a+b \mathrm{TL}$ & 0.061 & 0.764 & 0.352 & $0.759-0.770$ & 0.996 \\
\hline \multirow{3}{*}{ C. saliens } & \multirow{3}{*}{149} & $\mathrm{TL}=a+b \mathrm{FL}$ & 0.171 & 0.892 & 0.311 & 0.885-0.899 & 0.999 \\
\hline & & $\mathrm{FL}=a+b \mathrm{SL}$ & -0.157 & 0.861 & 0.259 & $0.854-0.868$ & 0.999 \\
\hline & & $\mathrm{SL}=a+b \mathrm{TL}$ & -0.012 & 0.769 & 0.359 & $0.760-0.777$ & 0.998 \\
\hline
\end{tabular}

\section{DISCUSSION}

The $b$ values in LWR identify the growth type of the fish species. In a fish population, $b=3$ isometric growth and fish transform into more robust with an increase in length (Bagenal and Tesch, 1978), $b \neq 3$ allometric growth and fish becomes thinner with increasing length (King, 1996). The results of this study show that the growth of the C. auratus, M. cephalus, C. labrosus and C. saliens was isometric. In this study, the similarity and differences were observed in the length - weight relationship parameters compared to the results of other researchers (Table 3). Nikolsky (1963) stated that the environmental conditions in the fish habitat have positive or negative effects on growth. This may explain that same fish species in different habitats can show different growth types.

In the present research, the condition factor values were similar when compared to the other researcher's results (Egemen et al., 1999; Buhan, 1998; Hoşsucu, 2001). In contrast, Bilgin et al., 2006; Acarl1, 2007; Komolu-Johnson and Ndimele, 2010; Y1lmaz and Polat, 2011; Kasımoğlu and Y1lmaz, 2011 reported different condition factor values. These differences may be due to the nutrient capacity of the environment, population density, sampling time, sample size and age.

In conclusion, results of the present study provide basic information on the LWR, LLR, and condition of four grey mullet species. These results showed that grey mullet species in Köyceğiz Lagoon are well-developed and nutritional capacity of the environment is sufficient when they are considered in terms of their length-weight and condition. In this respect, we have considered that our results will contribute positively to the management of lagoon fisheries and to related studies to be carried out in the future.

In the present research, the condition factor values were similar when compared to the other researcher's results (Egemen et al., 1999; Buhan, 1998; Hoşsucu, 2001). In contrast, Bilgin et al., 2006; Acarl1, 2007; Komolu-Johnson and Ndimele, 2010; Y1lmaz and Polat, 2011; Kasımoğlu and Y1lmaz, 2011 reported different condition factor values. These differences may be due to the nutrient capacity of the environment, population density, sampling time, sample size and age. 
Table 3. Comparison of growth parameters of grey mullet species reported by different studies

\begin{tabular}{|c|c|c|c|c|c|c|c|}
\hline Species & Habitat & $\mathbf{n}$ & $\mathbf{a}$ & b & $\mathbf{r}^{2}$ & $\begin{array}{c}\text { Growth } \\
\text { type }\end{array}$ & References \\
\hline \multirow{6}{*}{ 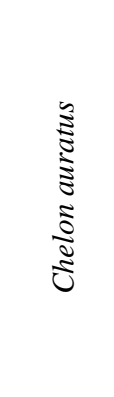 } & Köyceğiz Lagoon & 406 & 0.005 & 3.193 & 0.98 & I & Buhan, 1998 \\
\hline & Mar Menor Lagoon & 2955 & 0.0073 & 3.18 & 0.99 & $+\mathrm{A}$ & Verdiel-Cubedo et al., 2006 \\
\hline & Homa Lagoon & 119 & 0.0100 & 2.99 & 0.98 & I & Acarli et al., 2014 \\
\hline & Gediz Estuary & 81 & 0.0091 & 3.035 & 0.99 & $+\mathrm{A}$ & Kara et al., 2017 \\
\hline & Middle BlackSea & 255 & 0.044 & 2.52 & 0.87 & I & Samsun et al., 2017 \\
\hline & Köyceğiz Lagoon & 476 & 0.0087 & 2.96 & 0.99 & I & This study \\
\hline \multirow{6}{*}{ 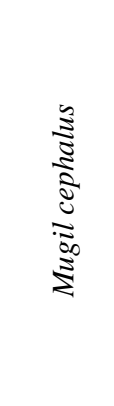 } & Köyceğiz Lagoon & 284 & 0.0012 & 2.95 & 0.95 & I & Buhan, 1998 \\
\hline & Strymon Lagoon & 290 & 0.0128 & 2.779 & 0.81 & $-A$ & Koutrakis and Tsikliras, 2003 \\
\hline & Vellar, Pakistan & 390 & 0.0232 & 2.76 & 0.99 & $-A$ & Murugan et al., 2012 \\
\hline & Persian Gulf & 37 & 0.0234 & 2.91 & 0.96 & $-A$ & Khayyami et al., 2014 \\
\hline & Okrika Gulfs & 30 & - & 2.86 & 0.96 & I & Ogunola and Onada, 2017 \\
\hline & Köyceğiz Lagoon & 291 & 0.0106 & 2.95 & 0.99 & $\mathbf{I}$ & This study \\
\hline \multirow{6}{*}{$\begin{array}{r}3 \\
0 \\
0 \\
0 \\
0 \\
0 \\
0 \\
\frac{0}{0} \\
0\end{array}$} & Köyceğiz Lagoon & 65 & 0.0013 & 2.931 & 0.99 & I & Buhan, 1998 \\
\hline & Güllük Lagoon & & 0.0001 & 3.084 & 0.98 & I & Egemen et al., 1999 \\
\hline & Rihios Lagoon & 88 & 0.0106 & 2.993 & 0.96 & I & Koutrakis and Tsikliras, 2003 \\
\hline & Homa Lagoon & 68 & 0.0080 & 3.061 & 0.83 & I & Acarl1 et al., 2014 \\
\hline & Gediz Estuary & 113 & 0.0083 & 3.090 & 0.99 & $+\mathrm{A}$ & Kara et al., 2017 \\
\hline & Köyceğiz Lagoon & 279 & 0.0073 & 3.06 & 0.99 & $\mathbf{I}$ & This study \\
\hline \multirow{6}{*}{ 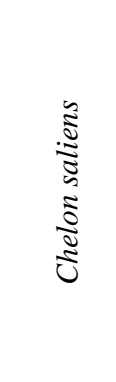 } & Köyceğiz Lagoon & 257 & 0.010 & 2.95 & 0.96 & I & Buhan, 1998 \\
\hline & Erdek Gulf & 57 & 0.0092 & 3.008 & 0.98 & I & Keskin and Gaygusuz, 2010 \\
\hline & Beymelek Lagoon & 1248 & 0.0099 & 2.95 & 0.97 & I & Balık et al., 2011 \\
\hline & Gediz Estuary & 91 & 0.0098 & 2.988 & 0.99 & I & Kara et al., 2017 \\
\hline & Homa Lagoon & 177 & 0.0018 & 3.489 & 0.95 & $+\mathrm{A}$ & Acarl1 et al., 2014 \\
\hline & Köyceğiz Lagoon & 149 & 0.0067 & 3.04 & 0.99 & I & This study \\
\hline
\end{tabular}

In conclusion, the results of the present study provide basic information on the LWR, LLR, and condition of four grey mullet species. These results showed that grey mullet species in Köyceğiz Lagoon are well-developed and nutritional capacity of the environment is enough when they are considered in terms of their length-weight and condition. In this respect, we have considered that our results will contribute positively to the management of lagoon fisheries and to related studies to be carried out in the future.

Acknowledgements: This study was funded by Muğla Sitkı Koçman University, Scientific Research Project Office with project number 17/119. 


\section{REFERENCES}

Acarl, D. (2007). Studies on fisheries and improving its fishery in Homa lagoon [PhD thesis]. Ege University Institute of Science and Technology, İzmir, Turkey $153 \mathrm{s.}$

Acarlı, D., Kara, A., \& Bayhan, B. (2014). Length-weight relations for 29 fish species from Homa Lagoon, Aegean Sea, Turkey. Acta Ichthyologica et Piscatoria, 44(3), 249-257. doi: 10.3750/AIP2014.44.3.09

Bagenal, T. B., \& Tesch, F. W. (1978). Age and growth. In: Methods for assessment of fish production in fresh waters. IBP Handbook No. 3. T. Bagenal (Ed.). Blackwell Scientific Publications, Oxford, pp.101-136.

Balık, S., Emre, Y., Sümer, C., \& Teksam, İ. (2011). Population structure, growth and reproduction of leaping grey mullet (Liza saliens Risso, 1810) in Beymelek Lagoon, Turkey, Iranian Journal of Fisheries Sciences, 10, 218-229.

Bilgin, S., Bircan, R., Sümer, Ç., Özdemir, S., Çelik, E.Ş., Ak, O., Satılmış, H.H., \& Bayraklı, B. (2006). Population features and reproduction biology of golden grey mullet Liza aurata (Risso, 1810) (Pisces: Mugilidae) in the Middle Black Sea (Sinop-Samsun Regions). Science and Engineering Journal of Firat University, 18, 49-62.

Blackwell, B. G., Brown, M. L., \& Willis, D. W. (2000). Relative Weight (Wr) Status and Current Use in Fisheries Assessment and Management. Reviews in Fisheries Science, 8, 1-44. doi:10.1080/10641260091129161

Buhan, E. (1998). Development of Lagoon Management of Köyceğiz Lagoon System by Researching Present Situtation and Grey Mullet Populations. Aquaculture Research Institute of Ministry of Agriculture, Bodrum. Serial B, 3, 1-347.

Egemen, Ö., Gökpınar, Ş., Önen, M., Büyükışık, B., Hoşsucu, B., Sunlu, U., \& Cirik, S. (1999). Güllük Lagoon (Aegean Sea, Turkey) Ecosystems. Turkish Journal of Zoology, 23, 927-947.

FAO, (1999). FAO species identification guide for fishery purposes. The living marine resources of the Western Central Pacific. 4 (2), 2069-2790.

Geldiay, R., \& Balık, S. (2009). Freshwater fish in Turkey. Ege University, Faculty of Fisheries Textbook, Series:46, VI. Press, Izmir, pp 648.

Hoşsucu, B. (2001). Some growth parameters of mullet species (Mugil spp.) living in Güllük Lagoon (Aegean Sea). Ege Journal of Fisheries and Aquatic Science, 18, 421-435.

Kara, A., Sağlam, C., Acarli, D., \& Cengiz Ö. (2017). Length-weight relationships for 48 fish species of the Gediz estuary, in İzmir Bay (Central Aegean Sea, Turkey). Journal of the Marine Biological Association of the United Kingdom, 98, 879-884. doi:10.1017/S0025315416001879

Kasımoğlu, C., \& Yılmaz, F. (2011). Growth and Reproduction Characteristics of the Striped Mullet (Mugil cephalus L., 1758) Inhabiting in the Gökova Bay (Mugla). Firat University Journal of Science, 23, $47-$ 55.

Keskin, Ç., \& Gaygusuz, Ö. (2010). Length-weight relationships of fishes in shallow waters of Erdek Bay (Sea of Marmara, Turkey). IUFS Journal of Biology, 69 (2), 87-94.

Khayyami, H., Movahedinia, A., Zolgharnein, H., \& Salamat, N. (2014). Length-weight relationship of Mugil cephalus (Linnaeus, 1758) from Bandar Abbas Port and Qeshm Island in northeastern Persian Gulf. Applied Science Research, 5(5), 19-23.

King, R. P. (1996). Length-weight relationship of Nigeria freshwater fishes. Naga ICLARM Quaterly, 19, 4952.

Koutrakis, E.T., \& Tsikliras, A.C. (2003). Length-weight relationships of fishes from three northern Aegean estuarine systems (Greece). Journal of Applied Ichthyology, 19, 258-260. doi:10.1046/j.14390426.2003.00456.x

Kumolu-Johnson, C.A., \& Ndimele, P.E. (2010). Length-weight relationships and condition factors of twentyone fish species in Ologe Lagoon, Lagos, Nigeria. Asian Journal of Agricultural Sciences, 2(4), 174179.

Moutopoulos, D. K., \& Stergiou, K. I. (2002). Length-weight and length-length relationships of fish species from Aegean Sea (Greece). Journal of Applied Ichthyology, 18, 200-203. doi:10.1046/j.14390426.2002.00281.x

Murugan, S., Ajmal Khan, S., Lyla, P.S., Prasanna Kumar, C., Jalal, K.C.A., Kamaruzzaman, B.Y., \& Akbar John, B. (2012). Length-weight relationship of Mugil cephalus (Linnaeus, 1758) in Vellar estuary, Southeast coast of India. Pakistan Journal of Biological Sciences, 15(12), 595-599. doi: 10.3923/pjbs.2012.595.599.

Nikolsky, G.V. (1963). The ecology of fishes. Academic Press, London.

Ogunola, O. S., \& Onada, O. A. (2017). Preliminary investigation of length-weight relationships and condition factors of two commercially important fish species (Mullet, Mugil cephalus (Linnaeus 1758) and Sardine, Sardinella maderensis (Lowe 1838)) in Okrika creeks (Niger-Delta) of Nigeria. Regional Studies in Marine Science, 13, 54-58.

Pauly, D. (1993). Fishbyte section editorial. Naga. ICLARM Quarterly, 16, 26. 
Ricker, W. E. (1975). Computation and interpretation of biological statistics of fish populations. Bulletin of the Fisheries Research Board of Canada, 191, 1-382.

Sağlam, C., Akyol, O., \& Ceyhan, T. (2015). Fisheries in Güllük Lagoon. Ege Journal of Fisheries and Aquatic Science, 32, 145-149. doi: 10.12714/egejfas.2015.32.3.04.

Samsun, O., Akyol, O., Ceyhan, T., \& Erdem, Y. (2017). Length-weight relationships for 11 fish species from the central Black Sea, Turkey. Ege Journal of Fisheries and Aquatic Sciences, 34 (4), 455-458. doi: 10.12714/egejfas.2017.34.4.13

Thomson, J.M. (1997). The Mugilidae of the world. Mem. Queensland Mus. 41, 457-562

Tsoumani, M., Liasko, R., Moutsaki, P., Kagalou, I., \& Leonardos, I. (2006). Length-weight relationships of an invasive cyprinid fish (Carassius gibelio) from 12 Greek lakes in relation to their trophic states. Journal of Applied Ichthyology, 22, 281-284. doi:10.1111/j.1439-0426.2006.00768.x

Verdiell-Cubedo, D., Oliva-Paterna, F.J., \& Torralva, M. (2006). Length weight relationships for 22 fish species of the Mar Menor coastal lagoon (western Mediterranean Sea). Journal of Applied Ichthyology, 22, 293-294. doi:10.1111/j.1439-0426.2006.00738.x

Weatherly, A.H., \& Gill, H.S. (1987). The biology of fish growth. London, academic Press. 433-443.

Y1lmaz, S., \& Polat, N. (2011). Age and Growth Properties of Striped Mullet, Mugil cephalus L., 1758 Inhabiting Bafra Fish Lakes, Samsun, Turkey. The Black Sea Journal of Sciences, 1, 1-19. 